\section{Marine Biology}

Volume 152, Number 4 / septembre 2007: 803-814

http://dx.doi.org/10.1007/s00227-007-0731-z

(c) 2007 Springer
Archimer, archive institutionnelle de l'Ifremer http://www.ifremer.fr/docelec/

The original publication is available at http://www.springerlink.com

\title{
Effects of water viscosity upon ventilation and metabolism of a flatfish, the common sole Solea solea (L.)
}

\author{
Christine Couturier ${ }^{1 *}$, Alice Rouault ${ }^{1}$, David McKenzie ${ }^{2}$, Robert Galois ${ }^{1}$, Serge Robert ${ }^{1}$, \\ Lucette Joassard $^{1}$ and Guy Claireaux ${ }^{2}$ \\ 1 Centre de Recherche sur les Ecosystemes Littoraux Anthropises, Place du Seminaire, \\ L'Houmeau, 17137 France. \\ 2 Institut des Sciences de l'Evolution de Montpellier, Station Mediterraneenne de \\ l'Environnement Littoral, 1 Quai de la Daurade, Sete, 34200 France. \\ * Email: christinecouturier@hotmail.com; Tel. +33 5465006 48, fax +33 546500600
}

\begin{abstract}
:
The French Atlantic coast contains large highly productive intertidal mudflats that are colonised by juveniles of numerous flatfish species, including the common sole (Solea solea, L.). These ecosystems are also heavily exploited by the shellfish farming industry. Intensive bivalve culture is associated with substantial biodeposition (1-6 t-dw ha-1 day-1), which directly or indirectly contributes to increase exopolysaccharide (EPS) concentrations at the interface between water column and seabed. EPS are long-chain molecules organised into colloids, which influence rheological properties of water, particularly viscosity. Increased water viscosity had consequences for ventilatory activity of juvenile flatfish, whereby the minimal pressure required to ventilate the medium increases directly with EPS concentration. Moreover, the critical EPS concentration ([EPS]crit) at which water was no longer able to flow through the branchial basket ranged from almost nil to over 30 mg I-1, depending on species and size. [EPS]crit was lower in small individuals and individuals from species with high metabolic rates (turbot and plaice). These differences may depend upon gill and bucco-branchial cavity morphometrics. The ventilatory workload of sole increased with viscosity to a maximum at $2 \mathrm{mg}$ EPS I-1. Viscosity might, therefore, be a limiting factor for flatfish post larvae, which colonise the intertidal mudflats, depending upon their size and species. EPS concentrations in the field can reach $15 \mathrm{mg} \mathrm{I-1.} \mathrm{A} \mathrm{selective} \mathrm{effect} \mathrm{is} \mathrm{conceivable} \mathrm{but} \mathrm{remains} \mathrm{to} \mathrm{be} \mathrm{estimated} \mathrm{in} \mathrm{the} \mathrm{field.}$
\end{abstract}

Keywords: Solea solea; Biodeposition; Water viscosity; Metabolism; Hypoxia; EPS 


\section{List of abbreviations}

$\dot{M} \mathrm{O}_{2}$ Oxygen consumption in $\mathrm{mgO}_{2}$ per unit of time $\left(\mathrm{h}^{-1}\right)$ and unit of mass $\left(\mathrm{kg}^{-1}\right)$

$\dot{\gamma} \quad$ Shear rate

$\% \quad$ Percent

${ }^{\circ} \mathrm{C} \quad$ Celsius degree

$\mathrm{cm}$ Centimetre

d Day

dw Dry weight

e Exponential

g Gram

$\mathrm{H}$ Difference in water height

$\mathrm{H}_{0} \quad$ Initial difference in water height

ha Hectare

$\mathrm{Hz} \quad \mathrm{Hertz}$

$\mathrm{km}^{2} \quad$ Square kilometre

1 Litre

L. Linnaeus

$\mathrm{ml} \quad$ Millilitre

mm Millimetre

$\mathrm{Pa}$ Pascal

T Time

t Tonnes

$\mathrm{y}, \mathrm{k}$ Parameters to estimate, $\mathrm{k}$ is the radius of curvature, $\mathrm{y}$ the asymptote value, i.e. yield stress

$\Delta P \quad$ Difference in pressure

$\mu \mathrm{m} \quad$ Micron 


\section{Introduction}

The French Atlantic coast comprises a series of intertidal mudflats the size of which ranges from about 10 (Aiguillon Cove) up to about $100 \mathrm{~km}^{2}$ (Marennes-Oléron or Arcachon Bays) (Verger 1968; Guarini et al. 1998). Specific physical and chemical conditions (sediment fineness, depth, light, salinity, temperature, emersion, mixing and river run-off) lead to high microphytobenthic productivity (Guarini et al., 1998). On that basis, it is believed that mudflats significantly influence the flux of matter and energy across coastal food webs (Leguerrier et al. 2003). Moreover, intertidal mudflats are crucial nursery habitats for numerous fish species, particularly for flatfishes (Gibson 1997).

Besides, along the Western coast of France, a total biomass of $150000 \mathrm{t}$ of oysters and $60000 \mathrm{t}$ of mussels is currently being cultivated (Goulletquer and Le Moine 2002). Large volumes of sea water are filtered by bivalves for feeding and respiration (Bougrier et al. 1995; Petersen et al. 2004). The most visible consequence of water filtration by cultured bivalves is the accumulation of faeces and pseudofaeces on seabed around farming facilities. For instance, shellfish culture in MarennesOléron bay was calculated to generate up to $600 \mathrm{t}$ dry weight ( $\mathrm{dw}$ ) of biodeposit per square km per day during periods of intense filtration (Sornin et al. 1986). Biodeposition promotes the development of microphytobenthos, primarily diatoms and bacteria (Barillé and Cognie 2000). These cells enhance the phenomenon of organic matter accumulation. They exude a mucilage layer to stabilise their micro-environment against physical and chemical disturbances (Decho 1990). This layer is chemically complex but comprises microbial extracellular polymeric substances including exopolysaccharides (EPS). EPS are long-chain molecules organised into colloids which are known to influence water rheological properties, specifically viscosity (Jenkinson and Biddanda 1995).

Small fish are faced with viscosity-related friction forces until their size allows inertial forces to prevail over viscous ones (Osse and Van den Boogaart 1999). The influence of viscous forces on the ability of young fish to move through water is well documented (Webb 1988; Fuiman and Batty 1997; Massel 1999). On the other hand, the influence of viscous forces on the ability of fish to ventilate water through their gill basket is poorly described. The mechanism of ventilation was illustrated by the action of two pumps functioning on either side of the gill resistance (Hughes, and Shelton 1958, Hughes 1960). First, the expansion of mouth entails a depression in the cavity. The water is drawn into the mouth, over the gills and into the opercular cavity. Then, the buccal cavity compressed while the gill one continues to expand. Once maximal compression is reached in buccal 
cavity, a unidirectional exit flow is maintained through opercular valves while gill cavity starts to compress. The gill curtain morphology appears determinant to minimize the work of ventilation conserving oxygen extraction efficiency. Recently, Jenkinson et al. (2007) demonstrated the profound effect of the rheological properties of water on the flow through branchial basket of sole (Solea solea). Particulate organic matter increases water viscosity (gelling) displaying more internal resistance to flow. The resistance induced was shown to interfere significantly with flow rate, depressing the flow until it stops completely. This impact seems to be fish mass dependant but has not been tested in vivo.

Our primary objective was to investigate the relationship between water EPS content, fish ventilatory activity and metabolic demand. First, we investigated the influence of water EPS content on yield stress. The yield stress is the minimum head pressure $\left(\mathrm{Pa}=\mathrm{kg} \mathrm{m}^{-1} \mathrm{~s}^{-2}\right)$ to apply to a fluid to make it begin to flow (Blair, 1933). Yield stress depends upon resistance displayed by (1) the system in which water flows (dimensions and characteristics) and (2) the intrinsic characteristics of the fluid (viscosity). Thus, to measure the yield stress allows assessing resistance displayed by the fluid in the respiratory cavity during ventilation (Jenkinson and Arzul, 1998). This threshold pressure is the minimum pressure fish have to produce to make water flow across their gills. The influence of fish size and species upon yield stress was assessed comparing sole with solenette (Buglossidium luteum, R), plaice (Pleuronectes platessa, L.) and turbot (Psetta maxima, L.). These species exhibit a broad range of active metabolic rates (AMR). For instance, AMR of 100 g-turbot, plaice and sole were measured respectively to be 305,230 and $160 \mathrm{mgO}_{2} \mathrm{~h}^{-1} \mathrm{~kg}^{-1}$ at $20^{\circ} \mathrm{C}$ (Mallekh and Lagardère 2002; Fonds et al. 1992; Lefrançois and Claireaux 2003). We hypothesised that species with low oxygen demand and, therefore, reduced gill area (Hughes 1972), would be less susceptible to water EPS load than species with high oxygen demand. To assess morphological differences, turbot and sole gill apparatus were dissected.

In a second set of experiments we examined the influence of water EPS content on ventilatory activity of sole, measuring frequency and amplitude of pressure changes in the opercular cavity during the ventilatory cycle. In order to quantify potential metabolic consequences of water viscosity on ventilatory work load, the standard metabolic rate (SMR) of young sole was measured in water containing various levels of EPS. The consequence upon tolerance to hypoxia was also examined by submitting these animals to an episode of progressive hypoxia. 
Additionally, we wanted to document EPS levels on mudflat habitats. We performed a seasonal and spatial field survey of EPS in the bottom water of the Pertuis Charentais, to gain insight into the ecological relevance of the limiting effects of EPS on flatfish ventilatory performance. This field survey was associated with a characterisation of the effects of EPS on the rheophysical properties of water.

\section{Materials and methods}

\section{Experimental fish}

Sole (1.1-22.3 g) and plaice (3.4 to $7.6 \mathrm{~g})$ were caught in the Aiguillon Cove and along the south coast of Ile de Ré using shrimping nets. Solenette (1.4-17.1 g) were trawled from the Pertuis Charentais (Y. Desaunay, RV Gwen Drez). Turbot (3.5-30.3 g) were obtained from a local hatchery (France Turbot, Noirmoutier Island). Upon arrival in the laboratory, fish were transferred into 5001 indoor tanks supplied with recirculated and biofiltered natural sea water at a temperature of $17^{\circ} \mathrm{C}$. Fish were kept under natural photoperiod and temperature conditions for at least 3 weeks prior to any experimentation. Three times a week, wild fish (sole, solenette and plaice) were fed to satiation with pieces of fresh mussels or oysters, whereas turbot were provided with commercial dry pellets. One week before experimentation, fish were transferred to a thermoregulated room at $15^{\circ} \mathrm{C}$, with artificial lighting that matched the natural photoperiod.

\section{Fluff sampling protocol}

Mud was collected weekly at low tide in the immediate vicinity of an oyster rearing facility (Pampin beach, l'Houmeau France). Only the first centimetre of the sediment was collected, comprising the substrate that flatfish species would inhabit, composed of light viscous mud known as "fluff". After homogenisation, samples were allowed to settle $2 \mathrm{~h}$ in order to separate the heaviest particles (sand) from the fluff. The superficial water was then removed and the fluff was gently retrieved and kept at $4^{\circ} \mathrm{C}$ to limit EPS degradation. According to Carlson (1987) no significant modification of viscosity occurs during the first 5 days following collection. 


\section{Biorheological effects of mud}

\section{Yield stress}

\section{Experimental set up and protocol}

The experimental set up was built according to Jenkinson et al. (2007). Briefly, it consisted of a small aquarium divided into two compartments (A and B) connected by a tube. Continuity was established between that tubing and fish gill cavity via the mouth. An initial difference in water height between the compartments (typically $2.7 \mathrm{~cm}$ ) allowed the fluid to flow by gravity from A to $\mathrm{B}$ via the gill chamber. The changes in hydrostatic pressure as water flowed through buccal and gill cavities were recorded continuously using a differential pressure transducer (Validyne Engineering Corp., Northridge, CA, USA), with the signal amplified (Gould Carrier Amplifier, Ballainvilliers, France) and acquired on a PC with custom-designed software (G. Guillou, Crela-L'Houmeau).

Fish were killed by submersion into seawater containing a lethal dose of anaesthetic (2phenoxyethanol, $2 \mathrm{ml} \mathrm{l}^{-1}$ ). A standard pipette tip was fixed hermetically to the fish mouth and then inserted in the tube connecting the two compartments of the experimental device. At that time, water level in both compartments was allowed to equilibrate in order to verify the calibration of the pressure sensor $(\Delta P=0)$. The valve between compartments was closed and $70 \mathrm{ml}$ of seawater added in A, generating a differential pressure corresponding to $290 \mathrm{~Pa}$. The valve was then opened and the changes in pressure difference between $\mathrm{A}$ and $\mathrm{B}$ was recorded $(40 \mathrm{~Hz})$. To obtain various EPS concentrations, the original fluff was diluted with sea water as following $0,5,10,20,30$ and $50 \%$ of fluff in sea water. Solutions were tested sequentially. At the end of each experiment, EPS concentration was determined in the original fluff as well as in the $20 \%$ diluted fluff. These measurements were used to calculate EPS concentrations in the other solutions using a linear regression. This experiment was conducted on sole (1.1-22.3 g), turbot (3.5-30.3 g), plaice (3.4-7.6 g) and solenette (1.4-17.1 g).

\section{Modelling and analyses}

Water flow through the gill cavity was modelled (NLREG ${ }^{\text {TM }}$ Software, Ph. Sherrod, Nashville, TN, USA) using the following equation:

$$
H=\left(H_{0}-y\right) * \mathrm{e}^{(-T / k)}+y
$$

where $H$ is the difference of water height between both compartments (Pascal), $T$ the time (s), $H_{0}$ the initial difference in water height (Pascal), $y$ and $k$ parameters to estimate (Jenkinson et al. 2007). 
The parameter $y$ corresponds to the value of the asymptote reached by the attenuation curve (considered as equilibrium), i.e. the yield stress and $k$ the radius of the curvature.

For each fish, yield stress (y) was expressed as a function of EPS concentration. At low EPS concentrations, yield stress is close to zero because water flow is largely independent of head pressure. However, above a critical EPS concentration, yield stress is positively and linearly related to EPS concentration. This critical EPS threshold was estimated for each fish as corresponding to the intersection point between two linear relationships (Fig. 1). Fish were categorized in three classes according to their mass: small $(<6 \mathrm{~g})$, medium $(6-12 \mathrm{~g})$ and large $(>12 \mathrm{~g})$.

\section{Ventilatory activity}

The experimental set up essentially consisted of a 31 plastic container and a differential pressure sensor interfaced with a computer. Pressure data were recorded continuously using customdesigned software (Rheosol, G. Guillou, Crela-L'Houmeau). Fish were anaesthetized (2phenoxyethanol, $0.67 \mathrm{ml} \mathrm{l}^{-1}$ ), weighed and their length measured. A flared polyethylene catheter (PE50 Intramedic) was passed through a hole drilled in the operculum, and secured with a cuff and sutures. Fish were then transferred to a small plastic chamber containing aerated seawater and allowed $1 \mathrm{~h}$ to recover. The water-filled catheter was then connected to the differential pressure transducer. Opercular pressure during the ventilatory cycle was recorded as described by Shingles et al. (2005). Experimental fluff solution was added sequentially to the holding container and 10 min after each addition the changes in opercular pressure amplitude and ventilatory frequency were measured during $1 \mathrm{~min}$ (Shingles et al. 2005). The following fluff dilutions were tested: 0, 5, 10, 15,20 and $30 \%$ of fluff in sea water. A water sample was collected after each dilution and EPS concentration was assayed.

In order to discriminate the effects of the mineral and organic fractions of the fluff, the same protocol was applied using mud samples treated beforehand with hydrogen peroxide $\left(\mathrm{H}_{2} \mathrm{O}_{2}\right)$ in order to destroy the organic fraction of the experimental fluid (Parker 1983). In both cases 6 soles were tested $(11.8 \pm 2.7 \mathrm{~cm}$ and $15.9 \pm 5.7 \mathrm{~g})$.

\section{Oxygen consumption}

Sole were used to test the impact of fluff upon SMR and critical oxygen concentration $\left(\mathrm{O}_{2 \text { crit }}\right)$. The experimental set up was similar to that described in Lefrançois and Claireaux (2003). Briefly, two respirometers (1.16 1) were used in parallel. These respirometers were placed in a larger tank which 
contained thermoregulated water $\left(15^{\circ} \mathrm{C}\right)$. Water oxygenation was regulated via a counter-current gas equilibration column placed upstream from the respirometer and bubbled with air, in control condition, or nitrogen to induce hypoxia. Respirometers were supplied with water from the outer tank at a flow rate of 2-3 $1 \mathrm{~min}^{-1}$ via a pump connected to a timer. Oxygen concentration in respirometers was measured using oxygen probes (Orbisphere Laboratories 27141, Houston, TX, USA) connected to a multichannel oxygen measuring system (Orbisphere Laboratories 2610) and a computer. Two pumps ensured water homogenisation inside the respirometers. Oxygen probes were calibrated daily. Determination of oxygen consumption was carried out after turning off the pump controlling water supply to the respirometers. This pump was turned off automatically for 15 min and the water oxygen concentration $\mathrm{C}_{\mathrm{w}} \mathrm{O}_{2}$ was continuously recorded. In order to ensure an appropriate equilibrium between fish oxygen demand and the lag time of the experimental set-up, only the last $7 \mathrm{~min}$ of each 15-min oxygen monitoring periods was used to calculate oxygen consumption.

\section{$\underline{\text { Standard metabolic rate }}$}

Sole SMR was determined 2 days after fish were placed in the respirometers. Three situations were tested. In the first case $(\mathrm{n}=8 ; \mathrm{w}=12.85 \pm 1.00 \mathrm{~g})$, a thin layer of sand was spread on the bottom of the respirometer and this was considered as an EPS-free control condition. The second situation (n $=6 ; \mathrm{w}=13.25 \pm 1.52 \mathrm{~g}$ ) allowed testing the effects of EPS on basal metabolic demand when fluff is added to the water $\left(1.13 \mathrm{mg}\right.$ EPS. $\left.\mathrm{l}^{-1}\right)$. The third situation $(\mathrm{n}=6 ; \mathrm{w}=13.67 \pm 1.10 \mathrm{~g})$ tested the effect of fluff previously treated with $\mathrm{H}_{2} \mathrm{O}_{2}$ to remove organic matter (Parker 1983). At the end of each experiment, fish were removed from the experimental set-up, the respirometer chambers were closed and background bacterial oxygen consumption was assessed. Fish oxygen consumption $\left(\dot{M} O_{2}\right.$ in $\left.\mathrm{mgO}_{2} \mathrm{~h}^{-1} \mathrm{~kg}^{-1}\right)$ was calculated from the net slope of decrease in oxygen concentration in the respirometer and adjusted according to a mass of $25 \mathrm{~g}$ as described in Lefrançois and Claireaux (2003). Sole oxygen consumption followed a daily pattern of variation, with higher values observed during the night and lower values during day time. In order to determine SMR, the first decile was used to cut the cumulative distribution curve of each fish $\dot{M} \mathrm{O}_{2}$ data set (Sokal and Rohlf 1995). This level avoided measurement errors and corrected for the effects of activity. The first decile was calculated for each set of experimental data and averaged per type of substratum. 


\section{Hypoxia}

Following SMR determination, nitrogen was bubbled in the gas equilibration column placed upstream from the respirometer chambers and a stepwise decrease (step: $1 \mathrm{mg} \mathrm{l}^{-1}$ ) in the water oxygenation was initiated (down to $1 \mathrm{mg} \mathrm{l}^{-1}$ ). At each step, fish oxygen consumption was determined. The relationship between routine metabolic rate and ambient oxygenation level was modelled using the following equation:

$$
\dot{M} O_{2}=\mathrm{a} * \ln \left[\mathrm{O}_{2}\right]+\mathrm{b}
$$

where $\dot{M} \mathrm{O}_{2}$ is the metabolic rate corrected for a body mass of $25 \mathrm{~g}\left(\mathrm{mg} \mathrm{O}_{2} \mathrm{l}^{-1} \mathrm{~kg}^{-1}\right)$ and $\left[\mathrm{O}_{2}\right]$ the concentration of oxygen in water $\left(\mathrm{mg} \mathrm{l}^{-1}\right)$. The confidence interval $\left(\mathrm{CI}_{95 \%}\right)$ of the estimated parameters was calculated.

\section{Field survey of seasonal and spatial variability in water EPS content}

Field EPS concentration was monitored in water samples collected at the interface with the seabed. This survey considered three different space scales. At macro-scale $(100 \mathrm{~km})$, across the Pertuis Charentais, ten samples were collected in four oyster culture zones presenting different silting up characteristics (Daire, Fouras, Rivedoux, Bellevue (France); Fig. 2a). The survey was repeated in January, May and September 2005. Samples were collected directly under the metallic frames holding the bags containing oysters. At meso-scale $(1 \mathrm{~km})$, ten samples were collected at four sites along a transect parallel to the coast, following the main current direction and crossing an oyster culture zone (Rivedoux; Fig. 2b). This sampling was also repeated in January, May and September 2005. Finally, at micro-scale, we examined the extent to which EPS exuded and accumulated on the bottom at low tide were stirred up by the tidal wave. Six samples were collected in Fouras in January 2005 under a frame holding oyster bags. In that case, samples were collected every 5-15 min over a 45-min-period. Sampling took place during a rising neap tide.

\section{Fluff characteristics}

Samples used for laboratory experiments were first characterized in terms of their water and organic matter content $(\%)$. Fluff samples $(20 \mathrm{ml})$ were weighed, dried at $50{ }^{\circ} \mathrm{C}$ for 3 days and reweighed to determine water content. A second set of samples $(100 \mathrm{ml})$ was weighed, dried at 450 ${ }^{\circ} \mathrm{C}$ for $12 \mathrm{~h}$ and re-weighed to determine organic matter content. 
Prior to EPS determination samples were freeze dried, crushed and kept at $-20{ }^{\circ} \mathrm{C}$ until analysed. EPS contents were measured (triplicate) using the phenolic-sulfuric acid assay developed by Dubois et al. (1956) and modified by Gershakov and Hatcher (1972). Briefly, colloidal carbohydrates were first extracted from freeze dried sediment with hot distilled water $\left(60{ }^{\circ} \mathrm{C}, 1 \mathrm{~h}\right)$ then precipitated in ethanol. They were measured by colorimetric method using a phenol-sulphuric acid assay with D-glucose dissolved in $\mathrm{H}_{2} \mathrm{O}$ used as standard.

Then, to keep only the mineral part of fluff, EPS were removed according to a method adapted from Parker (1983). A volume of $100 \mathrm{ml} \mathrm{H}_{2} \mathrm{O}_{2}$ was poured in 100 g-fluff samples. At the end of the reaction mineral particules were allowed to settle and water in excess was retrieved and replaced by the same volume of fresh water. This protocol was repeated three times with fresh water and twice with sea water.

Viscosity measurements were realised using a Physica MCR 301 rheometer (Anton Paar, Courtaboeuf, France) equipped with a cone-plate geometry (PP50/P2-SN3444). The sample thickness was set at $0.1 \mathrm{~mm}$ and temperature at $15^{\circ} \mathrm{C}$. Shear rate applied on samples was first increasing from $10^{-6} \mathrm{~s}^{-1}$ to $10^{-1} \mathrm{~s}^{-1}$ (one measurement each $4 \mathrm{~s}$ and 30 measurements), then decreasing from $10^{-1} \mathrm{~s}^{-1}$ to $10^{-6} \mathrm{~s}^{-1}$ (one measurement each $10 \mathrm{~s}$ and 30 measurements). Values of viscosity were obtained from decreasing shear rate measurements at $4.56 \times 10^{-3} \mathrm{~s}^{-1}$.

\section{Statistics}

The effect of size class and species on yield stress was analysed using a two way ANOVA. Maximum pressures during the ventilatory cycle of sole, turbot and solenette were compared using a two way ANOVA (species and size class). The effect of the substratum (sand, mud and EPS-free mud) on standard metabolism was tested using a one way ANOVA. A two way ANOVA was conducted to test the effect of location and time of the year on the EPS content in water samples collected across the Pertuis Charentais. In order to homogenize the number of samples in the intersites comparison (Rivedoux, Fouras, Bellevue and Daire), only the ten samples of the $3^{\text {rd }}$ point (R3) were taken into account in Rivedoux. Post hoc paired comparisons were made using Tukey HSD test with $P$ set at 0.05 . 


\section{Results}

When sampling for wild fish, we were unable to collect the appropriate number of plaice in each of the three size categories. Therefore data on plaice were not included in the statistical analysis. However, since they contribute to our arguments, data are presented on Fig. 3.

\section{Biorheological effects of mud}

\section{$\underline{\text { Yield stress }}$}

Critical EPS concentration ([EPS $]_{\text {crit }}$ ), i.e. the inflection point in the relationship between yield stress and water EPS content, was influenced by both body size $(P=0.022)$ and species $(P=$ 0.014). As shown on Fig. 3, flow was suppressed at higher EPS concentration in larger fish than in smaller fish. Moreover, critical EPS concentration was significantly lower in turbot than in solenette, sole occupying an intermediate position.

\section{Ventilatory activity}

Increasing water EPS content from 0 to $2 \mathrm{mg} \mathrm{l}^{-1}$ resulted in a 1.5 fold increase in sole ventilatory frequency (from 59 to 85 beats $\mathrm{min}^{-1}$; Fig. 4). At that point, the ventilatory response levelled off. A decrease in opercular ventilation frequency was eventually observed for water EPS content $>4 \mathrm{mg}$ $1^{-1}$. To avoid ventilatory distress, fish were then quickly transferred to EPS-free water where they recovered. The amplitude of pressure changes during the ventilatory cycle displayed a mirror image

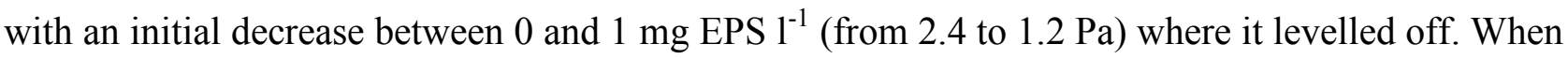
the same experiment was conducted with mud-free sea water or EPS-free mud $\left(\mathrm{H}_{2} \mathrm{O}_{2}\right.$-treated), no significant change in sole ventilatory activity was observed.

\section{Oxygen consumption}

Standard metabolic rate of sole was $37.6 \pm 4.42 \mathrm{mgO}_{2} \mathrm{~kg}^{-1} \mathrm{~h}^{-1}$ on a sandy substratum and $44.2 \pm$ $5.41 \mathrm{mgO}_{2} \mathrm{~kg}^{-1} \mathrm{~h}^{-1}$ in muddy conditions. When the organic fraction of mud was removed using $\mathrm{H}_{2} \mathrm{O}_{2}$, the SMR was $33.3 \pm 5.41 \mathrm{mgO}_{2} \mathrm{~kg}^{-1} \mathrm{~h}^{-1}$. These values were not statistically different.

Progressive hypoxia led to a parallel decrease in routine metabolic rate (Fig. 5). Critical $\mathrm{O}_{2}$ concentration $\left(\mathrm{O}_{2 \text { crit }}\right)$, i.e. the level of ambient $\mathrm{O}_{2}$ at which RMR equals SMR, was 2.47 and 2.15 $\mathrm{mg} \mathrm{O} \mathrm{O}_{2} \mathrm{l}^{-1}$ in EPS-free conditions (sand and treated mud respectively). In EPS loaded water, 
responses displayed much inter-individual variability in responses. For instance for four fish, $\mathrm{O}_{2 \text { crit }}$ was high $\left(\sim 5-7 \mathrm{mgO}_{2} \mathrm{l}^{-1}\right)$ while for the other two fish $\mathrm{O}_{2 \text { crit }}$ was low $\left(\sim 2 \mathrm{mgO}_{2} \mathrm{l}^{-1}\right)$. However, no significant difference was found among the three treatments.

\section{Fluff characteristics}

Fluff used in the current experiment contained $76.95 \pm 1.13 \%$ of water. Once dry, fluff contained $87.95 \pm 0.61 \%$ of inorganic matter and $12.05 \pm 0.61 \%$ of organic matter. Rheometrical analyses highlighted the fact that water viscosity increased exponentially with EPS concentration $(\mathrm{y}=$ $420.84 \times \mathrm{e}^{0.17 \mathrm{x}}, \mathrm{r}^{2}=0.76, P<0.001$; Fig. 6).

\section{Spatial and temporal variability of EPS content}

Across the Pertuis Charentais, water EPS concentration at the interface with the sediment was comprised between 0.2 and $15 \mathrm{mg} \mathrm{l}^{-1}$. At macro-scale, in the four oyster culture zones sampled, results showed a significant increase in EPS concentration in spring and late summer (May and September 2005; $P=0.0005$ ) compared to winter (January 2005) and a significant difference between sites $(P=0.0089$; Fig. 7a).

In Rivedoux, the meso-scale survey showed the same seasonal trend with higher values in May $(\mathrm{p}=$ 0.0028; Fig. 7b). EPS load was significantly higher at the $3^{\text {rd }}$ station compared to the other stations $(P=0.04)$ and a significant interaction between stations and seasons was found $(P<0.001)$.

Micro-scale survey (Fouras), showed that EPS concentration decreased with time as tide was rising $(\div 6$ in $40 \mathrm{~min}$; Fig. 7c), suggesting that turbulence was sufficient to stir up a part of the EPS exuded by diatoms during low tide.

\section{Discussion}

We demonstrated that increased water EPS load creates biologically-significant mechanical constraints upon ventilatory flow. Moreover, the rheological impact of EPS was more pronounced upon smaller fish and was species-dependent. In the field, water EPS concentration displayed spatial and temporal variability and was influenced by local hydrodynamic conditions. In some of shellfish farming areas we examined, EPS concentrations reached $15 \mathrm{mg} \mathrm{l}^{-1}$ a level we demonstrated to exert physiological limitations. 


\section{Biological effects}

The relationship between yield stress and water EPS content is biphasic (Fig. 1) with a first segment which is relatively flat until a critical EPS concentration is reached. Above that point, yield stress increases regularly with water EPS content. Jenkinson et al. (2007) revealed that this inflection point corresponds to a functional threshold above which the respiratory pump is unable to counterbalance the viscous forces generated by the EPS load. Indeed, during the ventilatory cycle, the maximum head pressure generated by young fish in EPS free-sea water ranged between 0.6 and $1.5 \mathrm{~Pa}$. This value is rapidely exceeded above $[\text { EPS }]_{\text {crit }}$ (Fig. 1). No value for ventilatory pressures has been previously reported in literature for such small animals, to allow us to draw comparisons with our data.

Flow patterns through fish gill cavity are essentially determined by physical constraints, namely fluid characteristics, speed of flow and characteristics of solid surface in contact with the moving fluid (Schlichting 1987). Viscosity is an important characteristic of fluids because it quantifies the amount of internal friction or resistance to flow. The higher the viscosity, the stronger the pressure that must be applied to the fluid to initiate flow. Accordingly, we found that yield stress increased with EPS content of the ventilatory medium. Furthermore, wall effects in buccal and gill cavities of fish are particularly significant. When a fluid flows over a stationary surface such as branchial basket, the fluid molecules in contact with surfaces are brought to rest by the shear stress. As a result, a boundary layer exists within which fluid velocity increases from zero at the gill surface to a maximum in the free stream. In a gill curtain comprising primary and secondary lamellae, the smaller the distance between adjacent lamellae, the lower the water velocity between them. Accordingly, we found that smaller individuals exhibited a higher yield stress than larger ones. As fish grow, the distance between secondary lamellae increases (Hughes 1984), as does the total volume of their buccal and opercular cavity (Kalinin et al. 2000). Thus, the volume available to water flow is larger in larger fish and the mean water velocity in the free stream is potentially higher.

The species-specific response to increased EPS load may result from morphological differences. The mass of the gill apparatus of turbot is 2.1 fold that of a sole of similar size and morphometric differences in fish gills of different species were shown to determine resistance to water flow (Hughes and Shelton 1958). We showed that $[\text { EPS }]_{\text {crit }}$ as a function of gill mass is higher in sole 
than for turbot (Fig. 8). Turbot is more sensitive to EPS load than sole. Furthermore, although we did not measure it directly, we can suppose that increased gill mass implies more surface area. This would be in accordance with previous observations showing that species with high metabolic rate are likely to have more developed gill apparatus with larger gill area, narrow spaced lamellae and longer filament making resistance to flow more elevated (Hughes 1966). Indeed, for instance at $20^{\circ} \mathrm{C}$, AMR of a 100 g-turbot (Mallekh and Lagardère 2002) is 1.9 fold higher than that of sole (Lefrançois and Claireaux 2003). Accordingly, it can be noticed that AMR of a 100 g-plaice is 1.4 fold that of sole at the same size (Preide and Holliday 1980). Unfortunately, we were unable to find published data on the relationship between gill size and body size for plaice or solenette. Therefore, because of their large gill apparatus, smaller space is available to water flow in turbot and plaice. Thus, they show greater impedance to flow of viscous medium and are more likely to be susceptible to changes in water viscosity.

In spite of their relative tolerance to [EPS], the ventilatory activity of sole is perturbed in a viscous medium. Opercular ventilation frequency increased with increasing water EPS concentration. Typically, increased ventilatory frequency is observed in situations involving increased metabolic demand (e.g., swimming, Roberts 1975; Altamiras et al. 2002; Wilson et al. 2002) or reduced oxygen availability (e.g., Maxime et al. 2000; MacCormack et al. 2003). Under these conditions, increased ventilatory frequency is generally associated with an increase in the amplitude of subopercular pressure excursions during the ventilatory cycle (Maxime et al., 2000; turbot). Together, these reflex responses increase the ventilatory volume, and so enhance the transfer of oxygen into the blood (Jensen et al. 1993). In the current study, the response of juvenile sole to increased water viscosity comprised a sharp increase in ventilatory frequency associated with reduced sub-opercular pressure changes. Presumably, frictional forces in the viscous medium interfered with the ability of the ventilatory pump to generate pressure, and so fish exhibited a compensatory increase in frequency in order to maintain gill irrigation. This is clear evidence of respiratory distress and, indeed, at EPS concentrations $>4 \mathrm{mg} \mathrm{l}^{-1}$, ventilation was completely inhibited and sole had to be quickly transferred to EPS-free water. At this point, frictional forces either exceeded the power of the ventilatory pump and/or resulted in muscular exhaustion (Maxime et al. 2000; Wilson et al. 2002) in relation with the sequential increases in fluff concentration.

Although exposure to fluff influenced ventilation patterns, this was not related to any significant effects upon SMR. The absence of any effect of fluff on basal metabolic demand indicates that sole were able to meet their minimum oxygen requirements despite the increased viscosity of their 
respiratory medium. However, results upon $[E P S]_{\text {crit }}$ suggested a species-specific impact of the constraints imposed by EPS according to the oxygen requirements of the four species studied. Therefore, we might assume a species-specific impact of the level of EPS load in water upon their respective SMR and thus critical oxygen concentration in water $\left(\mathrm{O}_{2 \text { crit }}\right)$.

We initially hypothesized that increased EPS load and associated increased ventilatory work would result in reduced tolerance to hypoxia. Thus, an increase in the critical oxygen concentration $\left(\mathrm{O}_{2 \text { crit }}\right)$ was expected in sole maintained on a muddy substratum. Our data did not provide strong evidence for this. Animals on both sand and $\mathrm{H}_{2} \mathrm{O}_{2}$-treated fluff exhibited a similar metabolic response to hypoxia and shared a very similar $\mathrm{O}_{2 \text { crit }}$ of about $2 \mathrm{mgO}_{2} \mathrm{l}^{-1}$. On the contrary, animals in fluff exhibited a more variable metabolic response and, although their $\mathrm{O}_{2 \text { crit }}$ was not statistically different from that of the other two groups, Fig 5 shows that some animals on the fluff displayed immediate decline in the metabolic rate in hypoxia. This was never observed in sole exposed to either sand or treated mud. This indicates that some animals within a sole population may experience problems with maintaining both routine activities and also their minimal metabolic requirements if exposed to hypoxia when on fluff, whereas this appears not to be true for the other two substrata. Thus, although our data did not provide a statistically significant effect, there may nonetheless be an ecologically significant effect within a population of sole that attempts to colonise an area where the substrate contains high concentrations of EPS. Clearly, we might have found a significant effect on hypoxia tolerance if we had tested higher fluff concentrations $\left(>2 \mathrm{mg}^{-1}\right)$.

\section{Impact of shellfish farming facilities on mudflats characteristics and ecological implications}

Fluff organic content we measured in the vicinity of oyster culture zones are in accordance with values reported in the literature (Ragnarsson and Raffaelli 1999; Hartstein and Rowden 2004). These values are $\sim 6$ times higher than the values reported for oyster free areas (Vouvé 2000). EPS accumulation was more intense toward the centre of shellfish culture zone and this is probably due to reduced hydrodynamics in these areas (Hartstein and Rowden 2004). Our survey also revealed that biodeposition was variable among sampling sites, probably in relation with differences in local conditions (Le Hir et al. 2005) and in densities of bivalves being cultured. EPS load also displayed seasonal variations. Oyster filtration activity is closely correlated with seasonal elevations in temperature, doubling between 5 and $20^{\circ} \mathrm{C}$ (Bougrier et al. 1995). Likewise, seasonal changes in microphytobenthic development and EPS production have been documented (Underwood and Paterson 1993; Underwood 1994). These seasonal cycles have an influence on fluff 
organic/inorganic matter ratio. Sornin et al. (1983) showed that biodeposits contain a high proportion of mineral particles in winter, whereas the organic fraction was significantly increased $(+37 \%$ organic carbon in sediments) in spring and summer.

\section{Conclusions}

This study provided insight into the potential ecological significance of biodeposition and the extent to which this might determine the quality status of mudflats as nursery grounds for juveniles of benthic fish species. We demonstrated that EPS levels in the vicinity of intensive bivalve rearing facilities can have profound size-dependent and species-specific effects on gill water flow and ventilation in young flatfish. Various technical limitations prevented us from testing fish less than 5 $\mathrm{cm}$ in length but data already available (Jenkinson et al. 2007) indicates that constraints imposed by water EPS load will be even more pronounced in smaller fish, with potentially greater ecological consequences. Our results suggest that flatfish species with large gill areas and high oxygen requirements will be at greater risk of negative effects of EPS. This species-specific effect is therefore liable to alter the species composition of young fish communities occupying coastal mud flats. This effect is probably reinforced in systems that are subject to hypoxic events, where there will be even greater selective pressures upon the ability of a given individuals to extract oxygen from sea water.

\section{Acknowledgements}

Authors would like to thank Y. Desaunay, J. Grison, G. Guillou and M. Bréret for their technical assistance, C.C. was the recipient of a PhD fellowship from the Conseil Général de Charente Maritime. The financial support by the European Union, Directorate Fisheries, through contract QLRS-2002-00799, Project ETHOFISH, is also acknowledged. 


\section{References}

Altamiras J, Axelsson M, Claireaux G, Lefrançois C, Mercier C, Farrell AP (2002) Cardiorespiratory status of triploid brown trout during swimming at two acclimation temperatures. J. Fish Biol. 60: 102-116

Barillé L, Cognie B (2000) Revival capacity of diatoms in bivalve pseudofaeces and faeces. Diatom Res. 15: 11-17

Blair SGW (1933) On the Nature of “Yield-Value”. J. Appl. Phys. 4: 113-118

Bougrier S, Geairon P, Deslou-Paoli JM, Bacher C, Jonquières G (1995) Allometric relationships and effects of temperature on clearance and oxygen consumption rates of Crassostrea gigas (Thunberg). Aquaculture 134: 143-154

Carlson DJ (1987) Viscosity of sea-surface slicks. Nature 329: 823-825

Decho AW (1990) Microbial exopolymer secretions in ocean environments: their role(s) in food webs and marine processes. Oceanogr. Mar. Biol. Annu. Rev. 28: 73-153

Dubois M, Gilles KA, Hamilton JK, Rebers PA, Smith F (1956) Colorimetric method for determination of sugars and related substances. Anal. Chem. 28: 350-356

Fonds M, Cronie R, Vethaak AD, Van der Puyl P (1992) Metabolism, food consumption and growth of plaice (Pleuronectes platessa) and flounder (Platichthys flesus) in relation to fish size and temperature. Neth J Sea Res 29: 127-143

Fuiman LA, Batty RS (1997) What a drag it is getting cold: partitioning the physical and physiological effects of temperature on fish swimming. J. Exp. Biol. 200: 1745-1755

Gershakov SM, Hatcher PG (1972) Improved technique for analysis of carbohydrates in sediments. Limnol. Oceanogr. 17: 938-943

Gibson RN (1997) Behaviour and the distribution of flatfishes. J. Sea Res. 37: 241-256

Goulletquer P, Le Moine O (2002) Shellfish farming and Coastal Zone Management (CZM) development in the Marennes-Oleron Bay and Charentais Sounds (Charente Maritime, France): a review of recent developments. Aquaculture Int 10: 507-525

Guarini J-M, Blanchard G, Bacher C, Gros P, Riera P, Richard P, Gouleau D, Galois R, Prou J, Sauriau P-G (1998) Dynamics of spatial patterns of microphytobenthic biomass: interferences from geostatistical analysis of two comprehensive surveys in MarennesOléron Bay (France). Mar. Ecol. Prog. Ser. 166: 131-141

Hartstein ND, Rowden AA (2004) Effect of biodeposits from mussel culture on macroinvertebrate assemblages at sites of different hydrodynamic regime. Mar. Environ. Res. 57: 339-357

Hughes GM (1960) A comparative study of gill ventilation in marine teleosts. Journal of Experimental Biology 37: 28-45

Hughes GM (1966) The dimensions of fish gills in relation to their function. J. Exp. Biol. 45: $177-$ 195

Hughes GM (1972) Morphometrics of fish gills. Respir. Physiol. 14: 1-25

Hughes GM (1984) General anatomy of the gills. In: Hoar WS, Randall DJ (eds) Fish physiology. X, Gills - Part A, Anatomy, gas transfert and acid-base regulation. Academic Press, New York, pp 1-72 
Hughes GM, Shelton G (1958) The mechanism of gill ventilation in three freshwater teleosts. J. Exp. Biol. 35: 807-823

Jenkinson I, Arzul G (1998) Effect of the flagellates Gymnodinium mikimotoi, Heterosigma akashiwo and Pavlova lutheri on flow through fish gills. In: Reguera B, Blanco J, Fernández ML, Wyatt T (eds) Proceedings of 8th International Conference on Harmful Algae. Xunta de Galicia, Pontevedro and Intergovernmental Oeanographic Commission of Unesco, Vigo, Spain, pp 425-428

Jenkinson I, Biddanda B (1995) Bulk-phase viscoelastic properties of seawater: relationship with plankton components. J. Plankton Res. 17: 2251-2274

Jenkinson I, Claireaux G, Gentien P (2007) Biorheological properties of intertidal organic fluff on mud flats and its modification of gill ventilation in buried sole Solea solea. Mar. Biol. 150: $471-485$

Jensen FB, Nikinmaa M, Weber RE (1993) Environmental perturbations of oxygen transport in teleost fishes: causes, consequences and compensations. In: Rankin JC, Jensen FB (eds) Fish ecophysiology. Chapman \& Hall, London, UK, 9: pp 161-179

Kalinin AL, Severi W, Guerra CDR, Costa MJ, Rantin FT (2000) Ventilatory flow relative to intrabuccal and intraopercular volumes in the Serrasalmid fish Piaractus mesopotamicus during normoxia and exposed to graded hypoxia. Rev. Brasil. Biol. 60: 249-254

Le Hir P, Robert S, Chaumillon E, Walker P (2005) Etude pour la gestion dynamique des sédiments sur les côtes du bassin de Marennes-Oléron et le pertuis de Maumusson. Lot 4: Mesures et analyses - Conchyliculture / envasements / sables. IFREMER - CREOCEAN CLDG, La Rochelle

Lefrançois C, Claireaux G (2003) Influence of ambient oxygenation and temperature on metabolic scope and scope for heart rate in the common sole Solea solea. Mar. Ecol. Prog. Ser. 259: 273-284

Leguerrier D, Niquil N, Boileau N, Rzeznik J, Sauriau P-G, Le Moine O, Bacher C (2003) Numerical analysis of the food web of an intertidal mudflat ecosystem on the Atlantic coast of France. Mar. Ecol. Prog. Ser. 273: 147-162

MacCormack TJ, McKinley RS, Roubach R, Almeida-Val VMF, Val AL, Driedzic WR (2003) Changes in ventilation, metabolism, and behaviour, but not bradycardia, contribute to hypoxia survival in two species of Amazonian armoured catfish. Can. J. Fish. Aqua. Sci. 81: 272-280

Mallekh R, Lagardère J-P (2002) Effect of temperature and dissolved oxygen concentration on the metabolic rate of turbot and the relationship between metabolic scope and feeding demand. J. Fish Biol. 60: 1105-1115

Massel SR (1999) Fluid mechanics for marine ecologists. Springer, Berlin, Germany

Maxime V, Pichavant K, Boeuf G, Nonnotte G (2000) Effects of hypoxia on respiratory physiology of turbot, Scophthalmus maximus. Fish Physiol. Biochem. 21: 51-59

Osse JWM, Van den Boogaart JGM (1999) Dynamic morphology of fish larvae, structural implications of friction forces in swimming, feeding and ventilation. J. Sea Res. 55: 156174

Parker JG (1983) A comparison of methods used for the measurement of organic matter in marine sediment. Chem. Ecol. 1: 201-210 
Petersen JK, Bougrier S, Smaal AC, Garen P, Robert S, Larsen JEN, Brummelhuis E (2004) Intercalibration of mussel Mytilus edulis clearance rate measurements. Mar. Ecol. Prog. Ser. 267: $187-194$

Preide IG, Holliday FGT (1980) The use of new tilting tunnel respirometer to investigate some aspects of metabolism and swimming activity of the plaice (Pleuronectes platessa L.). J. Exp. Biol. 85: 295-309

Ragnarsson SA, Raffaelli D (1999) Effects of the mussel Mytilus edulis L. on the invertebrate fauna of sediments. J. Exp. Mar. Biol. Ecol. 241: 31-43

Roberts JL (1975) Active branchial and ram gill ventilation in fishes. Biol. Bull. US 148: 85-105

Schlichting H (1987) Boundary-layer theory. McGraw-Hill, Inc., New York, USA

Shingles A, McKenzie DJ, Claireaux G, Domenici P (2005) Reflex cardioventilatory responses to hypoxia in the flathead gray mullet (Mugil cephalus) and their behavioral modulation by perceived threat of predation and water turbidity. Physiol. Biochem. Zool. 78: 744-755

Sokal RR, Rohlf FJ (1995) Biometry : the principles and practice of statistics in biological research. W.H. Freeman and Compagny, New York, USA

Sornin J-M (1983) Effet des biodépôts de l'hûitre Crassostrea gigas (Thunberg) sur l'accumulation de matières organiques dans les parcs du bassin de Marennes-Oléron. J. Molluscan. Stud. 12A: $185-197$

Sornin J-M, Feuillet M, Héral M, Fardeau J-C (1986) Influence des cultures d'huîtres Crassostrea gigas sur le cycle du phosphore en zone intertidale : rôle de la biodéposition. Oceanol. Acta 9: $313-322$

Underwood GJC (1994) Seasonnal and spatial variation in epipelic diatom assemblages in the Severn estuary. Diatom Res. 9: 451-472

Underwood GJC, Paterson DM (1993) Seasonnal changes in diatom biomass, sediment stability and biogenic stabilization in the Severn estuary. J. Mar. Biol. Assoc. UK 73: 871-887

Verger F (1968) Marais et wadden du littoral français. Etude de géomorphologie. Thèse de Doctorat, Biscaye Frères imprimeurs

Vouvé F (2000) Régénération benthique dans les vasières intertidales de Marennes-Oléron : nature de la matière organique, son impact sur la production et l'incorporation de l'ammonium. Doctorat. Océanologie, Perpignan

Webb PW (1988) Simple physical principles and vertebrate aquatic locomotion. Am. Zool. 28: $709-725$

Wilson RS, Kuchel LJ, Franklin CE, Davison W (2002) Turning up the heat on subzero fish: thermal dependence of sustained swimming in an Antarctic notothenioid. J Therm Biol 27: 381-386 
Figure 1. Example of the relationship between $\Delta Y$ (yield stress) and EPS concentration for fish of equal size. The arrow indicates the inflection point, i.e. the $[\mathrm{EPS}]_{\text {crit }}$.

Figure 2. (a) Map of the Pertuis Charentais. Open circles (०) represent water sampling locations at the interface with seabed. The sample sites are oyster culture zone (dark grey). R: Rivedoux, F: Fouras, D: Daire, B: Bellevue. (b) Satellite pictures of the Rivedoux site. R1, R2, R3 and R4 are sites sampled respectively before, through and at the end of the oyster culture area (dark patch in the bay) according to the stream.

Figure 3. EPS concentration ( \pm SEM) from which the four fish species tested (solenette, sole, plaice and turbot) have to increase the ventilatory work, compared to work required in sea water without EPS. $\square$ represents small fish (1.2-6 g), $\square$ medium fish (6.1-12 g) and $\square$ large fish (12.1-30.3 g). Figures above bars indicate $\mathrm{n}$. The dotted line represents the maximal value when $\mathrm{n}=2$. Different letters means statistically significant differences of means.

Figure 4. Percentage variation in frequency (black symbols; mean \pm sem) and pressure amplitude (white symbols; mean \pm sem) of sole opercular ventilation as a function of fluff content, under two treatments: in EPS-free condition (triangles, fluff $\mathrm{H}_{2} \mathrm{O}_{2}$-treated) and with fluff containing EPS (circles; mg..$\left.^{-1}\right) ; n=6$.

Figure 5. Influence of water EPS and $\mathrm{O}_{2}$ concentration on metabolism of sole. Solid curve: sole routine metabolic rate (Eq. 2; means $\pm \mathrm{IC}_{95 \%}$, dashed curves) on (a) sand, $\mathrm{RMR}_{\text {sand }}=24.49 \ln \left(\mathrm{O}_{2}\right)+$ 15.43, (b) fluff containing 1.13 mgEPS $1^{-1}, \mathrm{RMR}_{\text {fluff }}=24.59 \ln \left(\mathrm{O}_{2}\right)+27.14$ and (c) EPS-free fluff, $\mathrm{RMR}_{\text {free }}=25.91 \ln \left(\mathrm{O}_{2}\right)+13.47$. Horizontal solid lines:standard metabolic rate (SMR). 
Figure 6. Rheological properties of mud. Exponential relationship between EPS concentration (mg $\left.1^{-1}\right)$ and viscosity (means $\pm \mathrm{SEM}, n=32 ;$ Viscosity $=420.84 \times \mathrm{e}^{0.165 \times \mathrm{EPS}} ; r^{2}=0.77$ ).

Figure 7. EPS concentrations in water at the interface of seabed (mean \pm SEM) measured at 3 different scales (a) Measures realised at four sites in the Pertuis Charentais in oyster culture areas. (b) Measures realised at four sites of an oyster culture area in the Bay of Rivedoux. (c) Measures realised at the same point of an oyster culture zone at various times after the tide started to rise.

January 05, May 05 and $\square$ September 05 . For (a) and (b), n = 10 samples at each point and each month, for (c) $n=1$ sample at each point.

Figure 8. $[\mathrm{EPS}]_{\mathrm{crit}}\left(\mathrm{mg} \cdot \mathrm{l}^{-1}\right)$ as a function of gill mass in sole $(\boldsymbol{\square})$ and turbot $(\square)$ for three size classes ( $\mathrm{S}<6 \mathrm{~g}, 6<\mathrm{M}<12 \mathrm{~g}, \mathrm{~L}>12 \mathrm{~g}$ ). No measurement for medium sole was possible. 


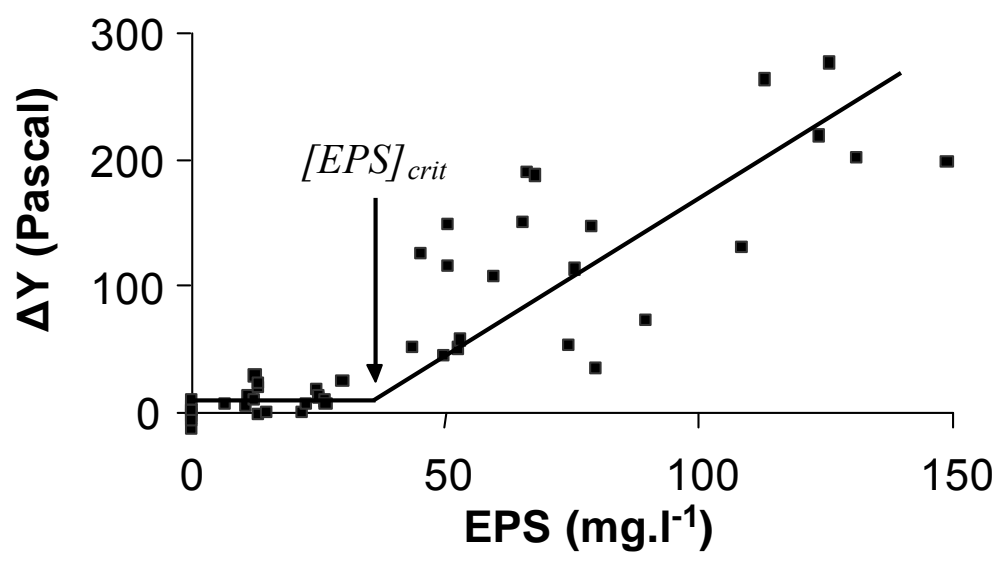

Figure 1. 
(a)

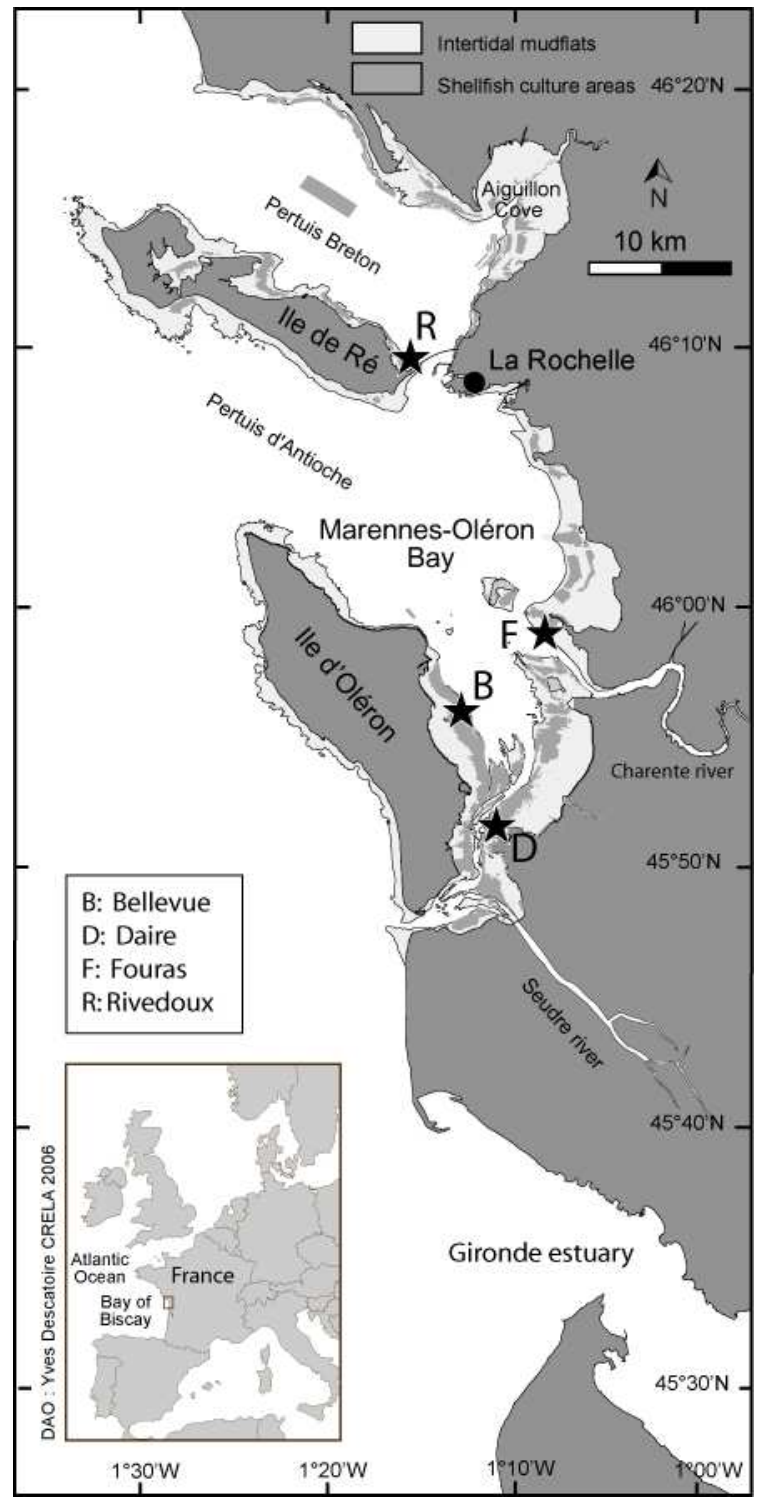

(b)

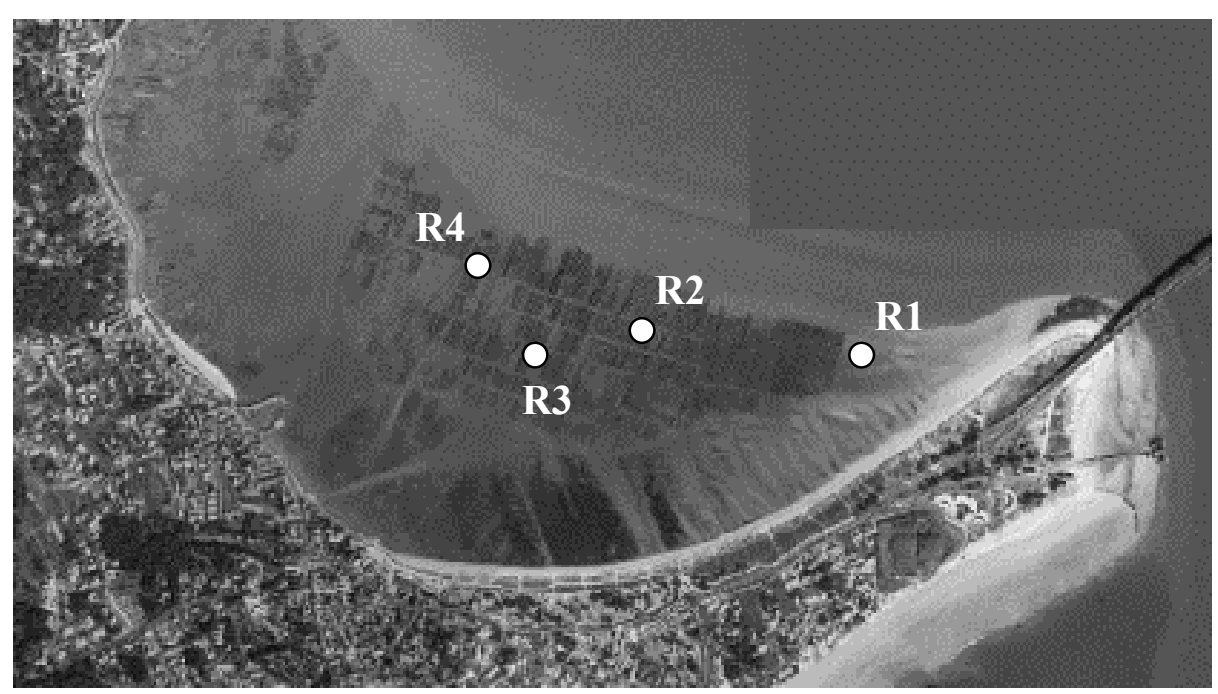

Figure 2. 


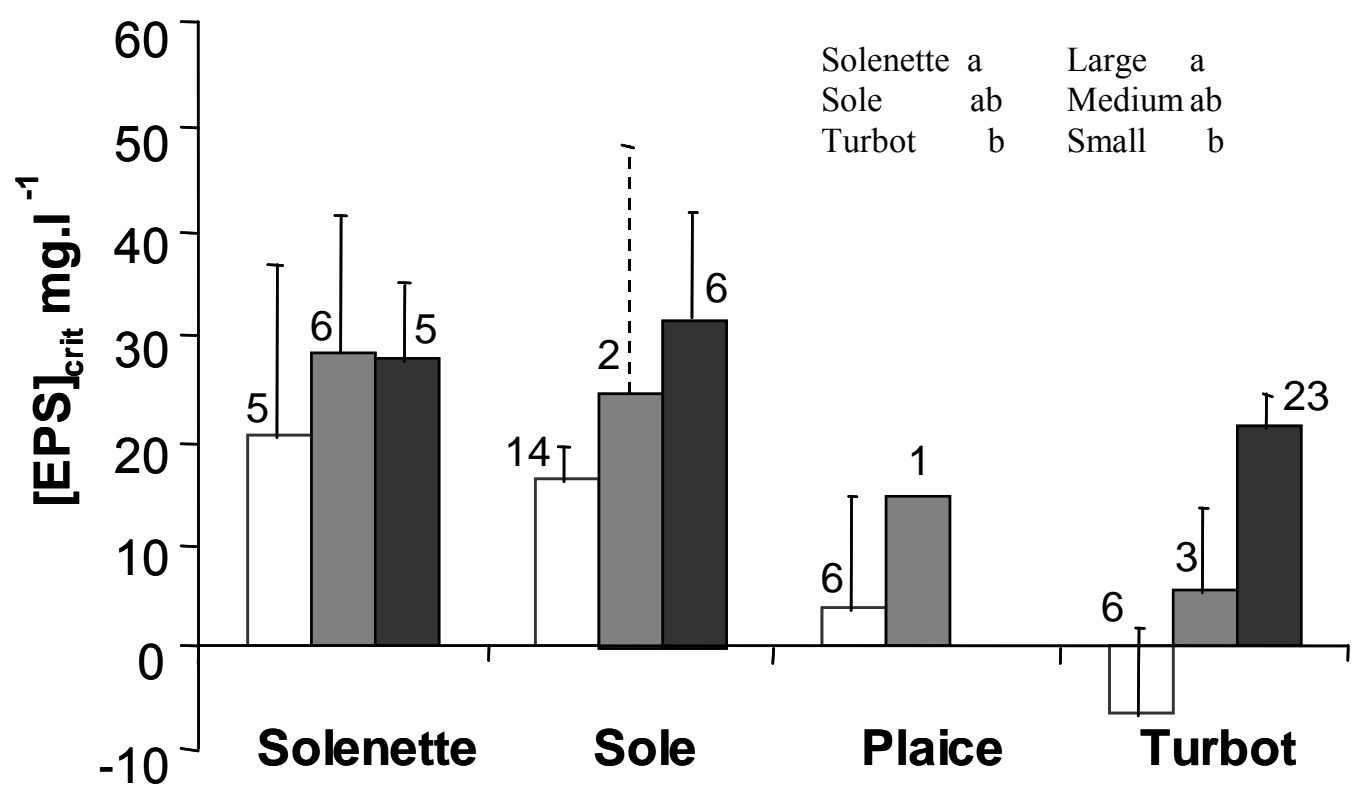

Figure 3. 


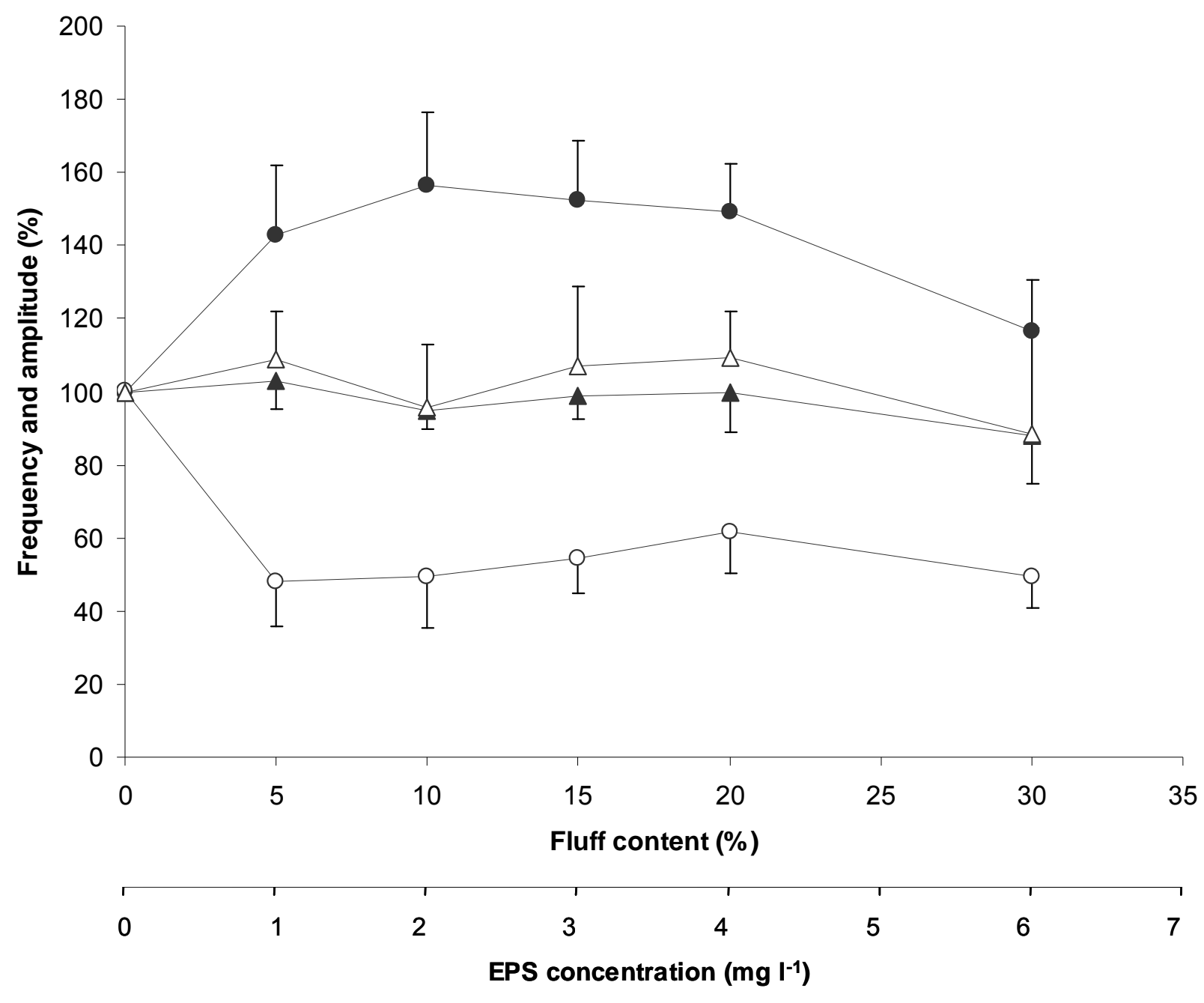

Figure 4. 
(a)

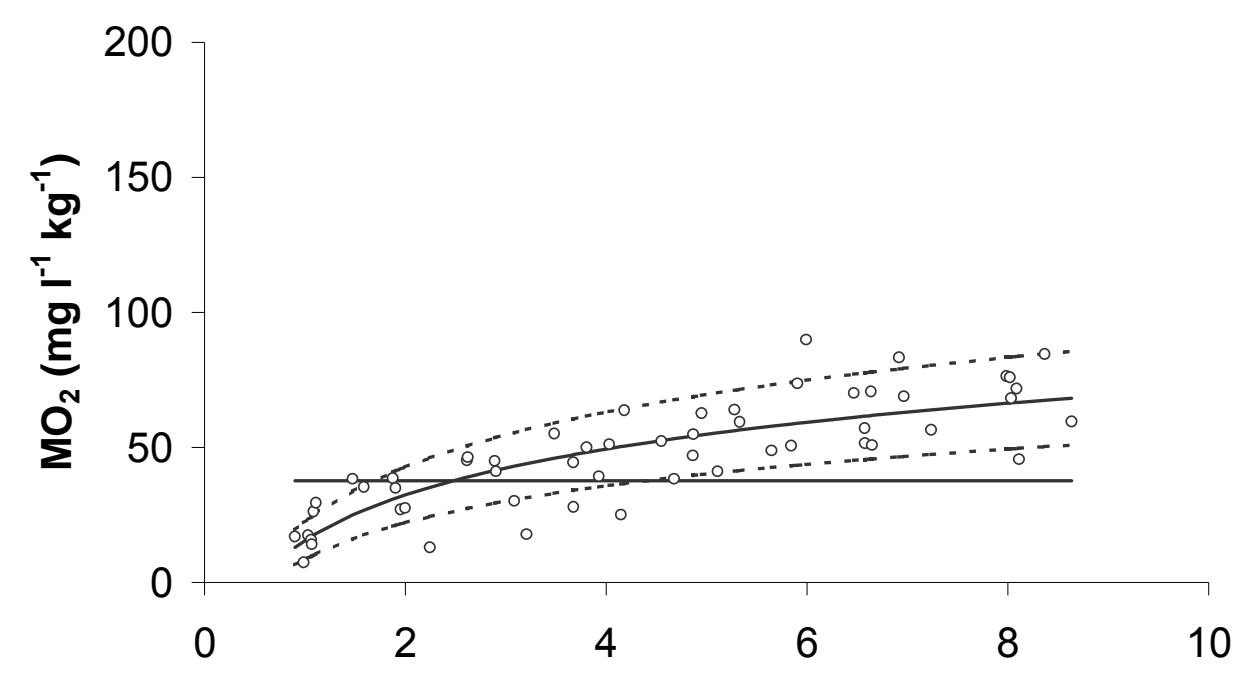

(b)

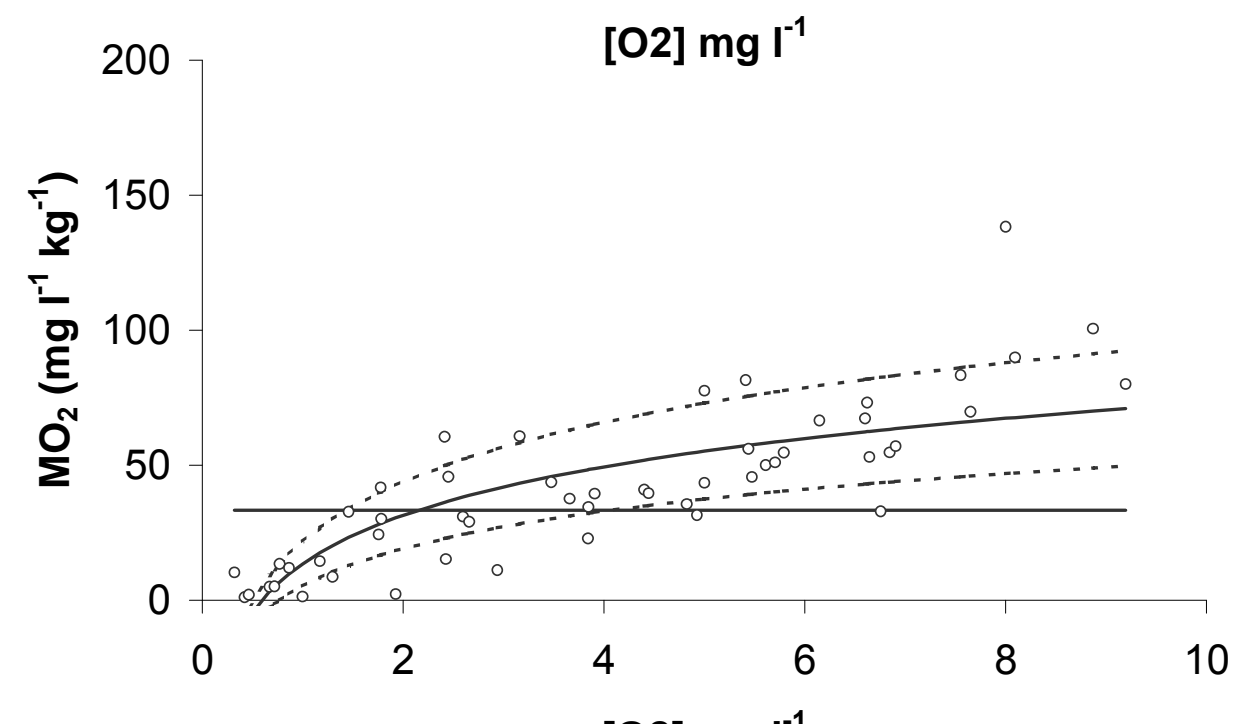

(c)

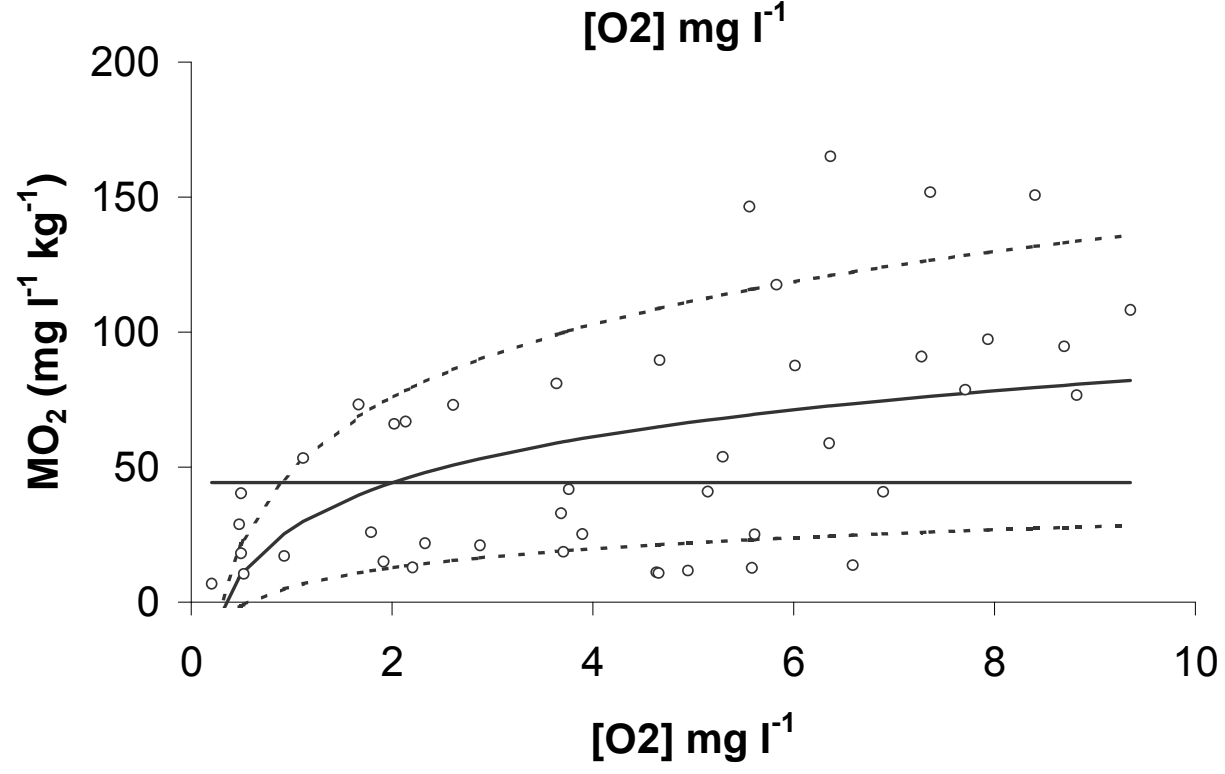

Figure 5. 


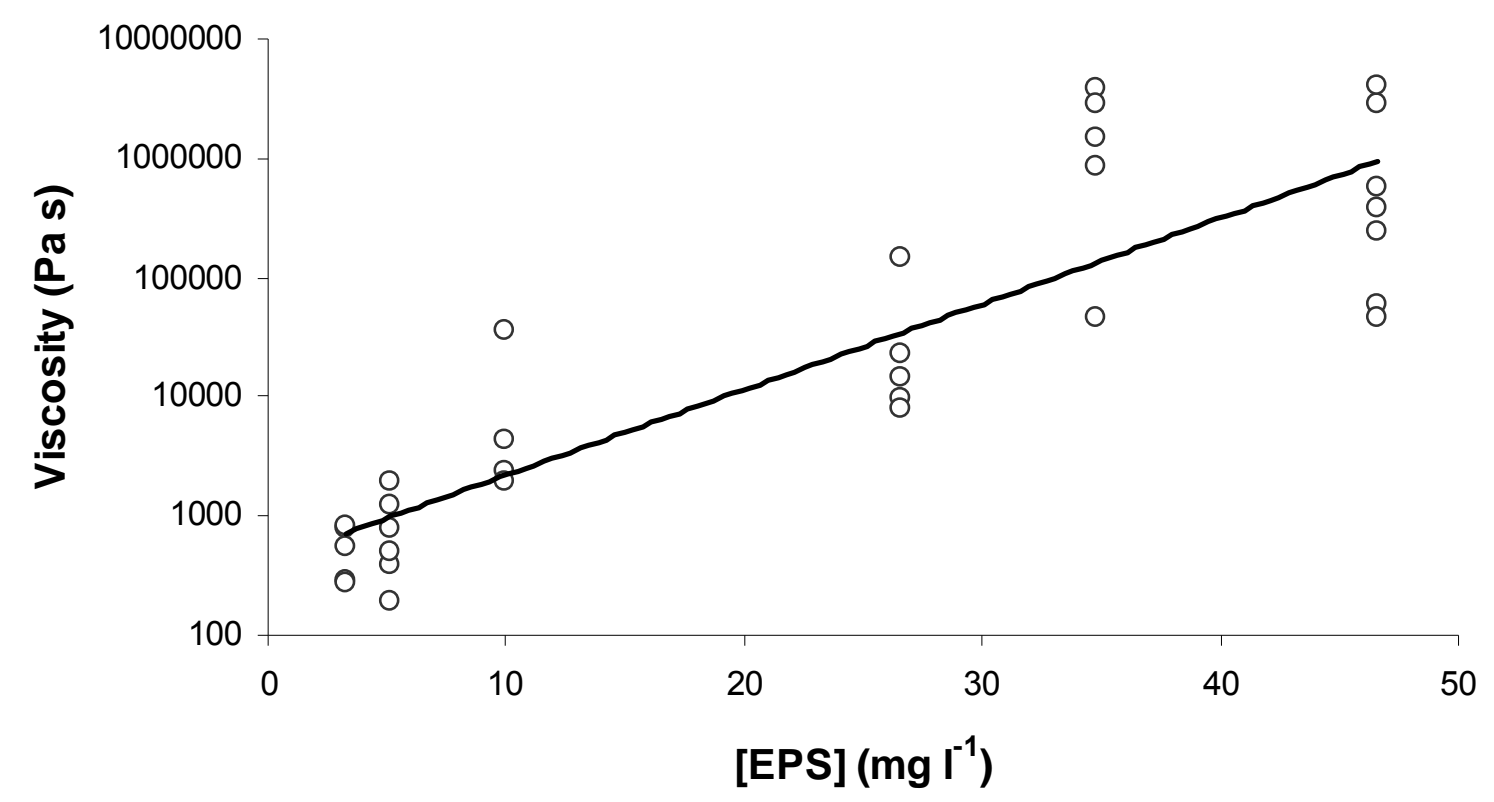

Figure 6. 
(a)

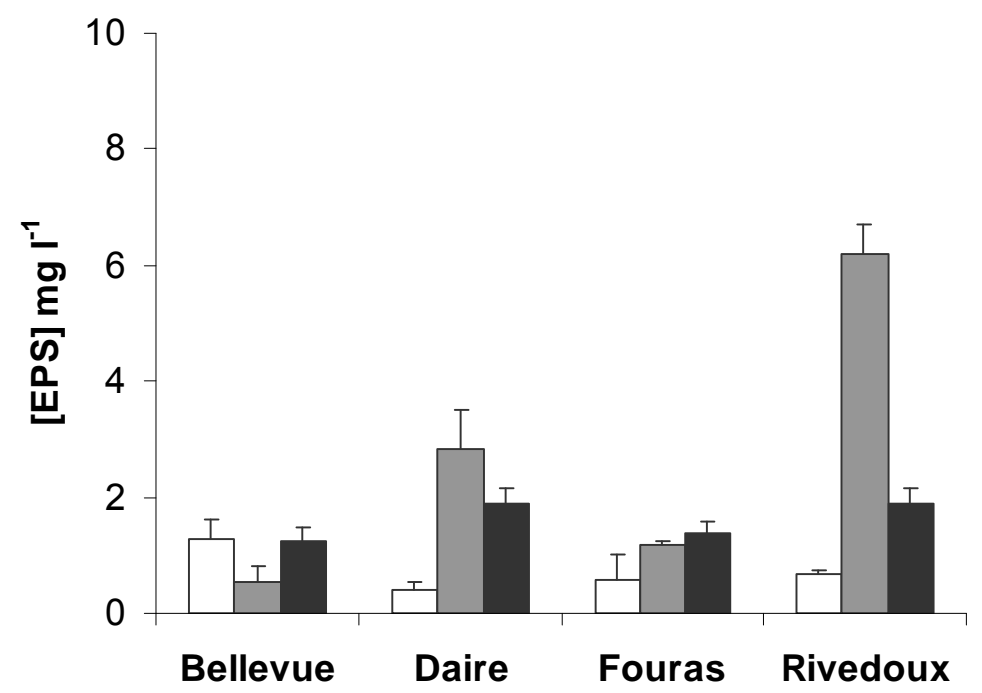

(b)

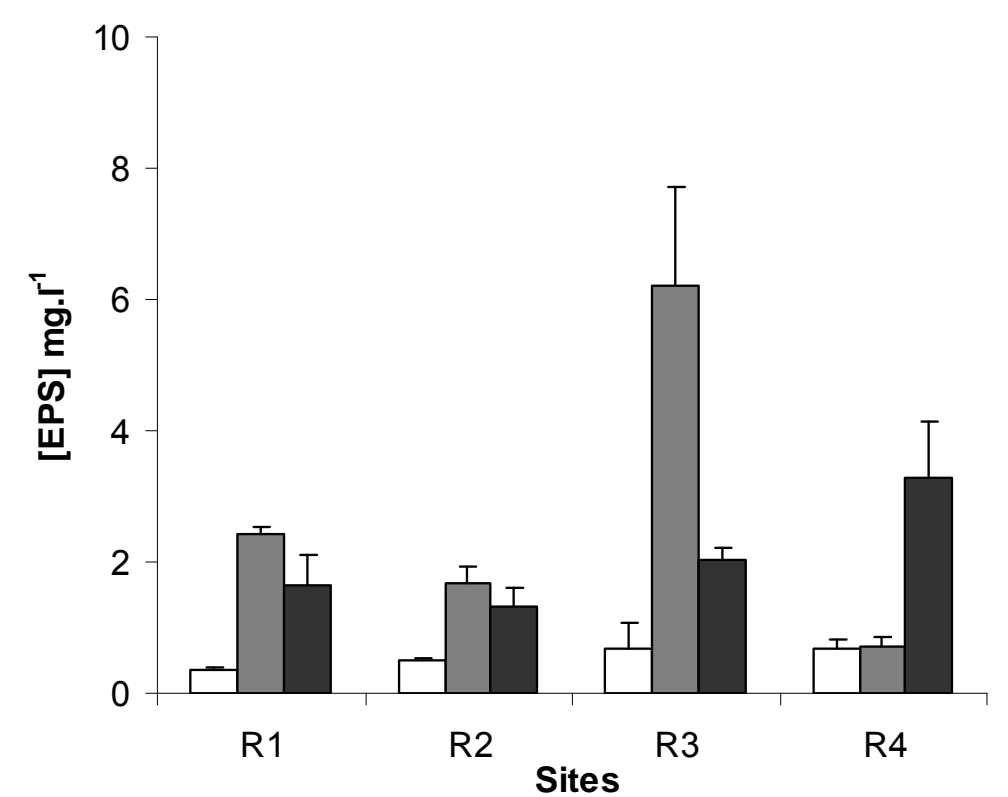

(c)

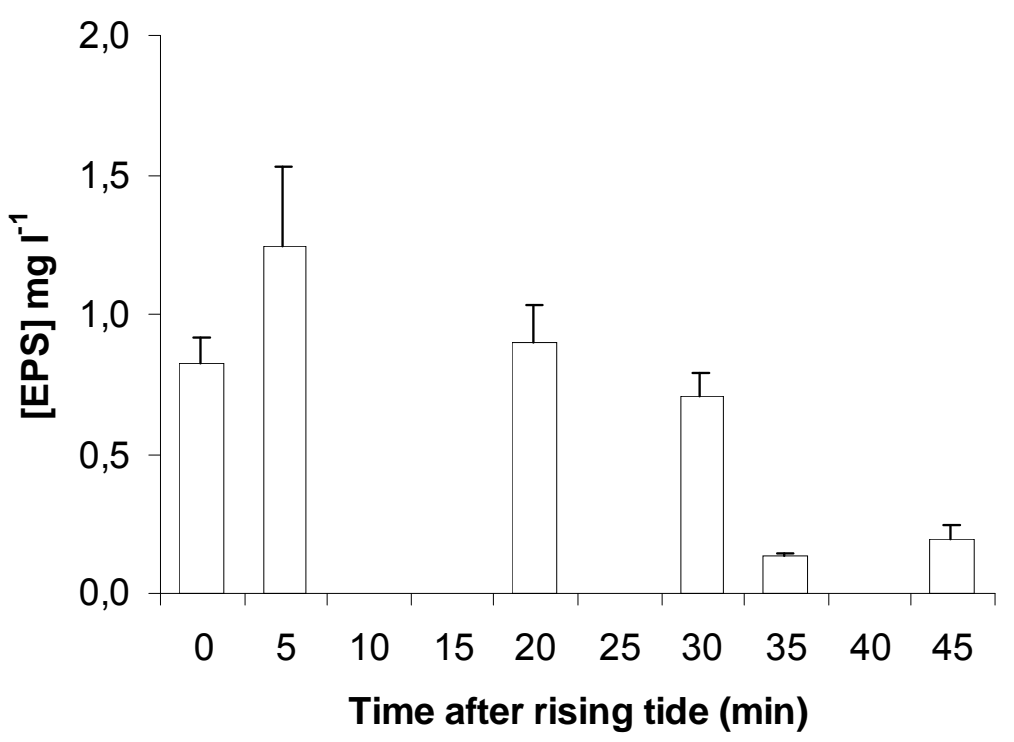

Figure 7. 


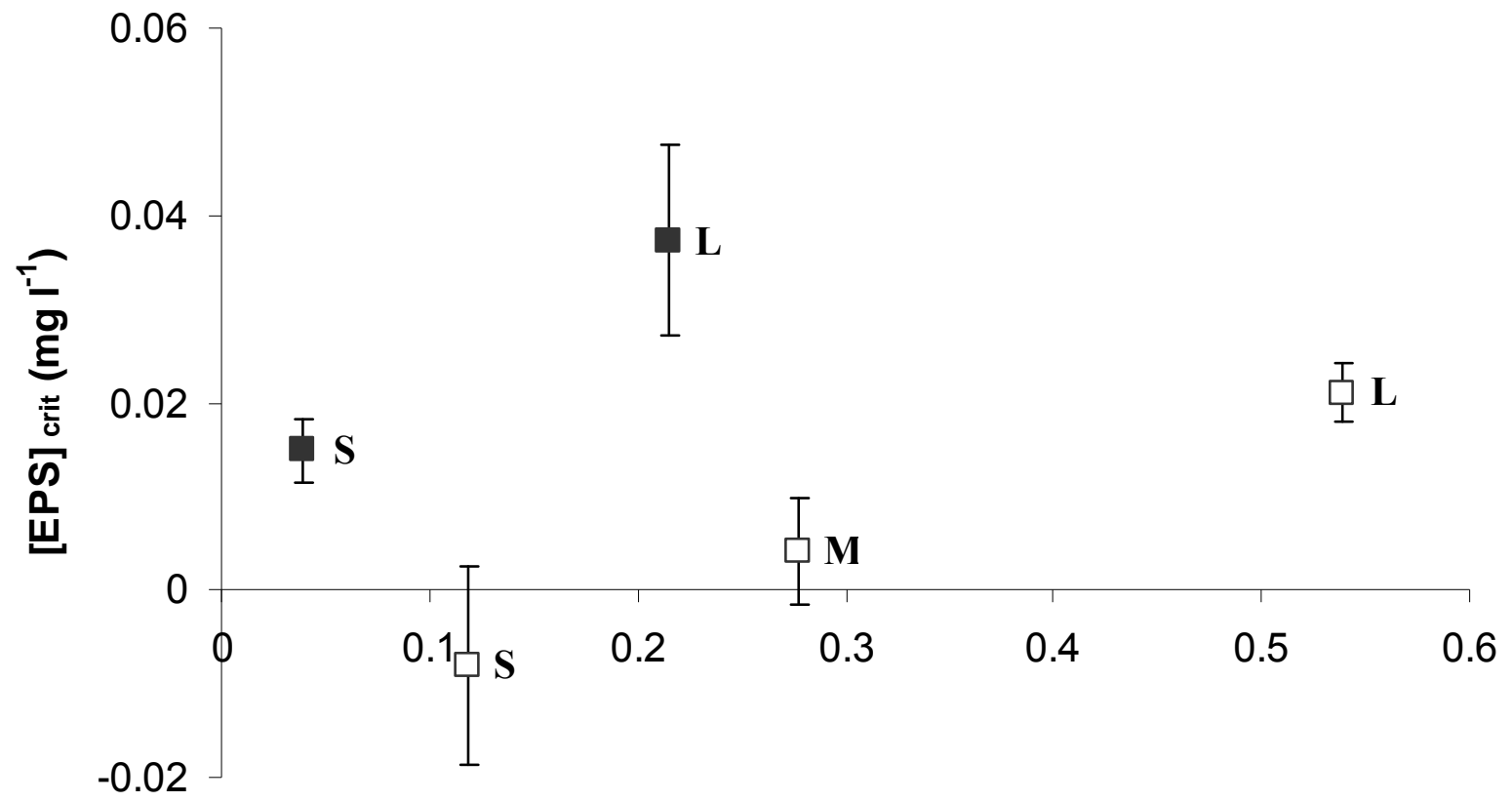

Gill mass (g)

Figure 8. 